RESEARCH PAPER

\title{
Hedging their bets: tobacco and gambling industries work against smoke-free policies
}

\author{
L L Mandel, S A Glantz
}

Tobacco Control 2004;13:268-276. doi: 10.1136/tc.2004.007484

See end of article for authors' affiliations

Correspondence to:

Professor Stanton A Glantz, $\mathrm{PhD}$, Center for Tobacco Control Research and Education, Room 366 Library, 530 Parnassus, University of California San Francisco, CA 94143-1390, USA glantz@medicine.ucsf.edu

Received 10 January 2004 Accepted 31 March 2004
Objective: To describe and understand the relationship between the tobacco and gambling industries in connection to their collaborative efforts to prevent smoke-free casinos and gambling facilities and fight smoke-free policies generally.

Methods: Analysis of tobacco industry documents available online laccessed between February and December 2003).

Results: The tobacco industry has worked to convince the gambling industry to fight against smoke-free environments. Representatives of the gambling industry with ties to the tobacco industry oppose smoke-free workplaces by claiming that smoke-free environments hurt gambling revenue and by promoting ventilation as a solution to secondhand smoke. With help from the tobacco industry, the gambling industry has become a force at the American Society of Heating Refrigeration and Air Conditioning Engineers opposing smoke-free ventilation standards for the hospitality industry.

Conclusion: Tobacco industry strategies to mobilise the gambling industry to oppose smoke-free environments are consistent with past strategies to co-opt the hospitality industry and with strategies to influence policy from behind the scenes. Tobacco control advocates need to be aware of the connections between the tobacco and gambling industries in relation to smoke-free environments and work to expose them to the public and to policy makers.
$\mathrm{T}$ he tobacco industry vigorously opposes smoke-free environments ${ }^{1-3}$ worldwide ${ }^{4-6}$ because they undermine the social acceptability of smoking and reduce cigarette consumption. $^{7}$ Because of its low public credibility, the tobacco industry works through front groups and third party allies to fight tobacco control measures at all levels. For example, at the local level, the tobacco industry has used public relations firms to organise "smokers' rights groups". ${ }^{23}$ At the international level, the tobacco industry has used its lawyers to secretly orchestrate scientific consultants to influence public and policymaker opinions on secondhand smoke. ${ }^{56}$ At all levels, the tobacco industry has organised or even created third party allies in the hospitality industry ${ }^{4}$ to oppose smoke-free environments and has worked through consultants to present ventilation or air cleaning as a viable alternative to smoke-free environments, particularly for the hospitality industry. ${ }^{9}{ }^{10}$ While continuing efforts to use the hospitality industry ${ }^{8}$ to oppose smoke-free policies ${ }^{4}{ }^{8}$ during the mid to late 1990s, the tobacco industry successfully mobilised the casino segment of the gambling industry to oppose smoke-free policies and promote ventilation as an alternative to smoke-free areas. In 1999, the US gambling industry was a $\$ 54$ billion dollar industry (gross revenue reported by operators before salaries, taxes, and expenses). ${ }^{11}$ The proliferation of legalised gambling, which includes the spread of casinos and other non-traditional gambling facilities licensed to operate video gambling machines, both in the USA and internationally, has made the use of the gambling industry a new and effective channel for the tobacco industry to oppose smoke-free policies from behind the scenes.

\section{METHODS}

We analysed approximately 1000 internal tobacco industry documents available online using standard techniques ${ }^{12}$ from February 2003 through December 2003. Initial searches were conducted using the keywords "gaming" and "casino", followed by searches of key individuals and organisations identified in the initial searches. Key individuals were mostly tobacco industry executives, consultants, or leaders of third party allies. For example, once Mayada Logue of Philip Morris (PM) had been identified as a key person responsible for working with casino interests, searches for "Logue, $\mathrm{M}^{\text {" or }}$ "Logue" and "gaming"" were conducted and documents analysed. Key organisations identified, such as the American Gaming Association (AGA), were also searched and analysed. We also searched adjacent Bates numbers for important documents to find related materials that may not have been well indexed.

In addition, we searched and analysed minutes and summaries of key state legislative hearings identified from initial searches. Newspaper databases available through Academic Universe and www.tobacco.org were conducted primarily at the beginning of the search process in order to determine where the indoor air quality debate included gambling facilities.

\section{RESULTS}

\section{Early connections}

Formal connections between the tobacco and gambling industries started as early as 1993 in Western Australia (table 1). A "privileged and confidential" five year plan of the Philip Morris (PM) legal department for 1994-1998 indicates that in 1993 the department "Assisted in the defense of Burswood Casinos in Australia against a claim by the state of Western Australia that employees were exposed to unsafe amounts of ETS [environmental tobacco smoke]". ${ }^{13}$ Dr Julian

Abbreviations: AGA, American Gaming Association; AHA, Australian Hotels Association; ASHRAE, American Society of Heating Refrigeration and Air Conditioning Engineers; $\mathrm{HCIAQ}$, Hospitality Coalition on Indoor Air Quality; HVAC, heating, ventilation and air conditioning; IAQ, indoor air quality; OSHA, Occupational Safety and Health Administration; PM, Philip Morris; RJR, RJ Reynolds 


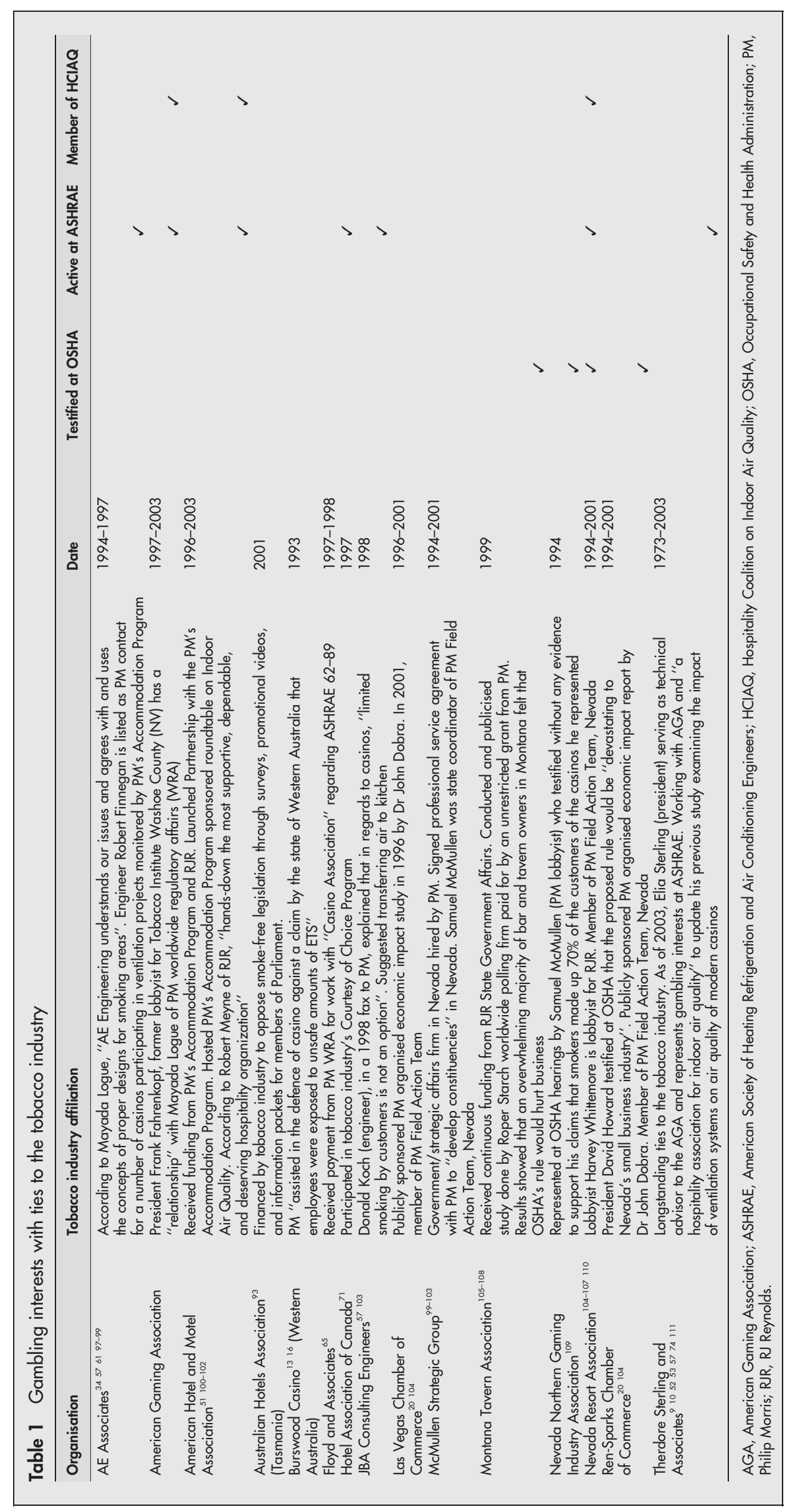


Lee, an Australian physician, testified that no diseases in adults are caused by acute exposure to secondhand smoke. ${ }^{14}$ It is not clear whether PM or the Burswood Casino paid for Lee's testimony. (Lee would later play an important role for the Tobacco Institute of Australia in their strategy to "set up an Independent Working group" to delay and discredit the 1997 Australian National Health and Medical Research Council report on passive smoking. ${ }^{15}$ ) The court dismissed the claims against the casino. PM saw the court's decision as an important victory. ${ }^{16}$

Inter-office correspondence circulated to senior management at PM regarding the Burswood decision outlines the steps taken to publicise the Burswood Casino victory in Australia and worldwide:

- in Australia, the Australian Hospitality Association [sic; probably referring to Australian Hotels Association] has prepared a press statement and letter to all members applauding the decision. A copy of their release will be disseminated to allies in the international and US hospitality associations along with a copy of the decision. Efforts will be made to get this information out through their channels with emphasis on those markets where smoking restrictions are currently in place or under consideration.

- discussions are underway to inform/involve casino and entertainment facility operators and association in the U.S. ${ }^{16}$

Formal connections between the tobacco and gambling industries in the USA appear to date from 1994, when the tobacco industry was mobilising opposition to the US Occupational Safety and Health Administration (OSHA) proposed rule that would have created smoke-free workplaces. ${ }^{17}{ }^{18}$ Even though the tobacco industry recognised that it had succeeded in holding back the rule at OSHA by 1998, ${ }^{19}$ the ongoing threat (until December 2001, when OSHA withdrew $\mathrm{it}^{18}$ ) provided a context and motivation for the tobacco industry to build an alliance with the gambling industry and ventilation engineers specialising in casinos. As in the hospitality industry, ${ }^{4}$ the tobacco industry worked to promote claims of negative economic effects of smoke-free environments on gambling revenue and ventilation as the solution secondhand smoke in gambling facilities.

\section{Procuring an economic study to mobilise the gambling industry}

PM worked to convince the gambling industry that OSHA's proposed rule would negatively affect them (and Nevada as a whole) by arranging for an "economic impact report". The report, "Economic impacts of the proposed OSHA smoking ban on the state of Nevada" 20 by Professor John L Dobra of the Natural Resources Institute at the University of NevadaReno, concluded that Nevada would lose 20000 to 30000 jobs, that overall economic activity would fall as much as $\$ 2.15$ billion, and that state and local government would lose $\$ 95$ million within one year of implementing OSHA's proposed workplace smoking regulation. ${ }^{20}$ The report was publicly released by the Greater-Reno Sparks and Las Vegas Chambers of Commerce in December 1996, who were identified as the sponsors. There was no mention of PM.

In fact, PM conceived of and organised the study with the goal of finding a third party sponsor to hide its involvement. ${ }^{21}$ By 18 July 1996, PM had reached an agreement with Dobra to prepare the report; at the same time PM staff noted that "efforts are under way to identify an appropriate sponsor for this survey". ${ }^{21}$ Two weeks later, on I August 1996 a PM OSHA communications report recorded that the Reno-Sparks
Chamber of Commerce had agreed to sponsor the study and that work on the survey was already underway. ${ }^{22}$ In addition, an internal PM email to the PM OSHA communications team noted that a PM economist "spent many hours working with Dr. John Dobra in Nevada to make sure that the economic study showing the impact of smoking bans on the state's gaming interests would be beyond reproach". ${ }^{23}$

The report and the attendant publicity effort may have been entirely funded by PM. On 7 January 1997, correspondence among executives within PM worldwide regulatory affairs (WRA) indicated that they had received a letter from Samuel McMullen, PM's lobbyist in Nevada, requesting \$25 000 from PM made payable to McMullen Strategic Group for the study. According to the correspondence, McMullen wrote:

The Las Vegas Chamber of Commerce and the Greater Reno-Sparks Chamber of Commerce have both been active in opposition to the proposed [OSHA] workplace ban and are interested to see if they are accurately representing their members on this important issue. The bulk of the funds will directed to a University of Nevada Professor, who is conducting the study, with a smaller amount set aside to be used to publicize the results. ${ }^{24}$

PM was directly involved in publicising the study at press conferences in Las Vegas and Reno on 4 December 1996. ${ }^{25}$ The day before the press conferences were held, BursonMarsteller, PM's public relations firm, faxed John Hoel (director of federal tobacco issues for PM Management Company) an executive summary of the report prepared by the McMullen Strategic Group, together with drafts of statements prepared for Brian Herr (chairman of the Greater-Reno Sparks Chamber of Commerce), Walt Collins and Tom Kapp (restaurant owners), and Dobra. ${ }^{26}$ Herr's remarks in Reno were identical, except for specifics relating to Las Vegas or Reno, to Mark Smith's (president and general manager of the Las Vegas Chamber of Commerce) remarks in Las Vegas. ${ }^{25}$ Articles about the study and the claim that Nevada would lose 50000 jobs in five years appeared in newspaper articles in Nevada and nationally. ${ }^{27-31}$

PM's role was not apparent in any public aspect of this report. In addition to failing to disclose PM's role, the report itself suffered from serious biases in the assumptions made in the calculations, which led to high estimates of negative affects among smokers and ignored the possibility that business from non-smokers might increase following implementation of a smoke-free policy. These problems are typical of industry funded "studies". ${ }^{32}$

\section{Selling ventilation as the "solution" for casinos}

The tobacco industry and its consultants promote ventilation as the "solution" to secondhand smoke for the hospitality industry. ${ }^{10}$ One of RJ Reynolds Tobacco Company's (RJR) central goals for 1996 was to "coordinate participation of RJR staff and consultants in planning and conducting a seminar to demonstrate how casino operators can effectively address issues related to ETS without losing business". ${ }^{33}$

PM monitored ventilation projects for casinos (table 1). In a 27 January 1997 email titled "Casino/Resort Gaming Industry" to Elizabeth Culley (of PM's Accommodation Program, ${ }^{4}$ which promotes ventilation as an alternative to smoke-free policies), Mayada Logue (senior analyst worldwide regulatory affairs) points out opportunities in the context of PM's comprehensive programme to promote ventilation within the hospitality industry. She explains that: 
$P M$ has a working relationship with $A E$ Engineering, one of the largest design firms doing work in the Casino/ Resort Area. This firm provided the HVAC [heating, ventilation, and air conditioning] engineering for the Luxor and the MGM Grand [casinos], just to name the most current jobs in Las Vegas. It also provided the engineering expertise for the newly designed casino in Kansas City and other "gaming boats" throughout the country. $A E$ Engineering understands our issues and agrees with and uses the concepts of proper design for smoking areas.

Because of our mutual inferests, the owner of AE recently informed us that ITT Sheraton and Planet Hollywood have joined together to build a new Casino in Las Vegas. During the process of selecting an engineering firm, ITT/ Planet Hollywood representatives stated that IAQ [indoor air quality] is an important issue to be addressed because [actors] D[emi] Moore, Arnold Sch-[warzenegger] and others, want to be able to enjoy their cigars. AE asked me if $P M$ would be interested in some involvement based on his knowledge of my goals. The engineering job has subsequently been awarded to $A E$. The project drawings have begun and I am scheduled to meet with AE at the end of the month to discuss possible opportunities for ventilation design/equipment demonstration. Let me point out that ITT Sheraton has announced its intention to open casino/resorts worldwide. ${ }^{34}$ [emphasis added]

PM also worked with the gambling industry on media and public relations programmes to promote ventilation for casinos. A 1998 PM Media Relations Program outlines tactics used by the Media Relations Program, including trade and mainstream media campaigns, designed to increase awareness of both the supply and demand for ventilation (heating, ventilation, and air conditioning, HVAC) systems in casinos. ${ }^{35}$ To reinforce the success of ventilation equipment to the "HVAC/ventilation community", PM planned to promote stories to trade publications on "new innovative uses of ventilation technology by the casino industry both at the table and in the ceiling". ${ }^{35}$ Likewise, to increase demand for HVAC systems among casino operators, PM planned to promote stories that "highlight and reinforce with a gaming/ casino publication new construction craze in Vegas, highlighting the role of HVAC in all new casino and hotel construction". ${ }^{35}$ PM sought to position HVAC as a prerequisite for all successful casinos and with the news hook of new construction in Las Vegas presented the tobacco industry with a new opportunity to showcase their public relations campaign of "exposure and awareness of reasonable options." 35

\section{Recruiting the American Gaming Association to lobby against smoke-free environments}

At the same time that PM was arranging for the Nevada economic study, RJR was pursuing a systematic partnership with the American Gaming Association (AGA), the gambling industry's main lobbying group. There were already longstanding informal ties, since before becoming the chief executive officer of the AGA in 1995, Frank Fahrenkopf had been a Tobacco Institute lobbyist in Nevada in $1975^{36}$ and a keynote speaker at Tobacco Institute meetings in $1984 .{ }^{37}$ In March 1996, RJR senior director of public affairs Robert Meyne wrote to Fahrenkopf to recruit the AGA to oppose OSHA's proposed regulation. Meyne wrote, "R.J. Reynolds and the American Gaming Association have a common interest in this issue. Our [RJR] position is that smoking policies in a casino, or any other business, should be developed by its owners and managers.... R. J. Reynolds is prepared to offer any assistance we can to you, your board, and members." ${ }^{\prime \prime 3}$

PM also sought a more formal connection with the gambling industry. In 1997, a PM draft budget increased its 1998 "special projects" budget from \$5.1 million to \$8.9 million to finance a "greater focus on Hospitality \& IAQ Programs". ${ }^{39}$ PM's manager of public affairs emailed Elizabeth Culley (Accommodation Program), John Hoel (director of federal tobacco issues, Washington Relations Office), and other PM executives in November 1997 reporting:

[W]e are going to capitalize on the Gaming/Hotel-Motel convention in Las Vegas to try to gain support from as many in this industry sector as we can for the resolution [Global Tobacco Settlement] ${ }^{40}$... Additionally, we will inventory our relationships with the Gaming [big]-wigs and see what meetings we can set up. Apparently, RJR has a relationship with Fahrenkopf from the American Gaming Association. John $\{$ Hoel\}, please advise if you find an internal relationship, otherwise, [we] can reach out to RJR to see if we can set up a Fahrenkopf/Carlton [Phil Carlton, former North Carolina Supreme Court Justice and a negotiator for the tobacco industry during the tobacco settlement] meeting. [We] will also be looking to see what other connections we have in the [gambling] industry. ${ }^{41}$

Despite these efforts, progress was slow for the tobacco industry. A February 1998 PM analysis of the gambling industry and the Accommodation Program recognised that the gambling industry did not share the tobacco industry's concerns about smoke-free regulations:

Efforts by the gaming industry, as a whole, to counter imposed indoor air quality standards have not been strong. Those that have been vocal included Wayne Mehl of the Nevada Resorts Association and Vann Heffner, also of Nevada. Research indicates that at present, the gaming industry does not feel threatened by the OSHA regulations. The AGA [American Gaming Association] has not formally addressed the issue and has not yet developed a division or department to create and industry position. ${ }^{42}$ Initial steps in developing an [gambling] industry-wide accommodation policy would assist in pre-empting any imposed regulatory pressures. However, without a developed industry position and a strong coalition of operators and ally groups, the [gambling] industry could very well face a costly, drawn-out contest with both the anti-smoking and anti-gaming lobbies. ${ }^{42}$ [emphasis added]

Even though PM's initial progress at developing a gambling industry position on indoor air quality was slow, they would successfully recruit the gambling industry to press the American Society of Heating, Refrigeration, and Air Conditioning Engineers (ASHRAE) to support the tobacco industry's position that ventilation could produce "acceptable" indoor air despite smoking. A PM inter-office memorandum dated 27 April 1999 from Deane Gross (PM group manager, event marketing) to PM's Hospitality Programs manager and Culley summarises "PM's involvement with the casino industry"43 and explains that PM WRA hired a consultant, Susan Floyd, in 1997 and $1998^{43}$ to work with Mayada Logue to mobilise the gambling industry:

[Floyd] worked very closely with Mayada Logue, focusing on ASHRAE and OSHA. She [Floyd] speaks very highly of 
Table 2 Hospitality Coalition on Indoor Air Quality (HCIAQ): broadening the coalition to include gambling (1999-2000). PM is no longer acknowledging membership (2003)

\begin{tabular}{|c|c|c|c|c|}
\hline \multirow[b]{2}{*}{ Organisation } & \multicolumn{2}{|c|}{ Attended membership meetings } & \multicolumn{2}{|c|}{ Publicly acknowledged members } \\
\hline & $\begin{array}{l}\text { September } 1999 \\
\text { meeting }^{112}\end{array}$ & $\begin{array}{l}\text { September } 2000 \\
\text { meeting }^{113}\end{array}$ & June $2003^{50}$ & December $2003^{51}$ \\
\hline Air Conditioning Contractors of America & $\checkmark$ & $\checkmark$ & $\checkmark$ & \\
\hline American Gaming Association & & $\checkmark$ & $\checkmark$ & $\checkmark$ \\
\hline American Hotel and Motel Association & $\checkmark$ & $\checkmark$ & $\checkmark$ & $\checkmark$ \\
\hline American Resort Development Association & & & $\checkmark$ & $\checkmark$ \\
\hline Bowling Proprietors Association of America & & & $\checkmark$ & $\checkmark$ \\
\hline Distinguished Restaurants of North America & & & $\checkmark$ & \\
\hline Hotel Employees Restaurant Employees International Union & $\checkmark$ & $\checkmark$ & $\checkmark$ & $\checkmark$ \\
\hline International Brotherhood of Teamsters & $\checkmark$ & $\checkmark$ & & \\
\hline $\begin{array}{l}\text { International Training Institute for the Sheetmetal } \\
\text { and Air Conditioning Industry }\end{array}$ & & $\checkmark$ & & \\
\hline National Energy Management Institute & & $\checkmark$ & $\checkmark$ & $\checkmark$ \\
\hline National Licensed Beverage Association & & $\checkmark$ & & \\
\hline National Restaurant Association & $\checkmark$ & $\checkmark$ & $\checkmark$ & $\checkmark$ \\
\hline Nevada Resort Association & & $\checkmark$ & $\checkmark$ & $\checkmark$ \\
\hline Philip Morris USA & $\checkmark$ & $\checkmark$ & $\checkmark$ & \\
\hline Sheet Metal Workers' International Union & $\checkmark$ & $\checkmark$ & $\checkmark$ & $\checkmark$ \\
\hline United Association of Plumbers and Pipefitters & $\checkmark$ & $\checkmark$ & $\checkmark$ & $\checkmark$ \\
\hline
\end{tabular}

Mayada and her dedication to spreading the word about ASHRAE in the casino world. For example, the Director of Public Affairs at Mirage Resorts (The Mirage, Treasure Island, Bellagio in Las Vegas, plus Atlantic City properties), Punum Mathur, became involved in ASHRAE issues only after Mayada introduced her to the subject a few years ago. The result is that IAQ has become a very high priority in the [gambling] industry. Punum chairs the legislative committee of the American Gaming Association (AGA). (AGA accepts ex-officio members and PM could join. ( $^{43}$

These efforts succeeded. According to Gross, Floyd felt that the gambling industry was in need of "strategic, candid advice" and the time was right for PM to be "quietly proactive on IAQ design and technical issues" and to educate the gambling industry on indoor air quality. ${ }^{43}$

PM worked with the gambling industry through the Hospitality Coalition on Indoor Air Quality (HCIAQ), proposed by Black, Kelly, Scruggs \& Healey, a BursonMarstellar Company. ${ }^{44}{ }^{45}$ On 22 November 1999, the proposed name, draft mission statement, and goals for the HCIAQ were sent to Culley from Black, Kelly Scruggs. ${ }^{44}$ The mission statement was:

The Indoor Air Quality Coalition is a partnership of labor, management, and business designed to present a unified voice in the marketplace and in the regulatory forums on issues that affect the hospitality workplace with regard to indoor air quality. Together we will seek solutions that promote vitality in the hospitality industry, maximize the industry's economic well-being and assure a comfortable environment for workers and patrons. ${ }^{44}$

A little over two months later, on 31 January 2000, Culley wrote to Steve Grover, co-chair of HCIAQ and National Restaurant Association vice president of health and safety regulatory affairs, explaining that $\mathrm{PM}$ was contributing \$250 000 to the HCIAQ. ${ }^{46}$ However, PM did not take credit for this support. Regarding the Restaurant Association Trade Show for 2001, Burson-Marstellar explained to Culley: "I can tell you that we have to remember that there are 13 different organizations involved with HCIAQ, and while PM is a significant funder of the coalition, sometimes I think 'less is more' when it comes to 'out front' PM involvement." ${ }^{\prime 47}$
A March 2001 report of HCIAQ highlights documents that the coalition had "Broadened the original membership of the coalition to now include representatives from the gaming industry" and explained that HCIAQ was "taking the lead to present at ASHRAE conference and explain hospitality point of view ${ }^{\prime \prime}{ }^{48}$ While PM was listed as a member of the HCIAQ when it was first launched (table 2$)^{49}$ and as late as June $2003,{ }^{50}$ by December 2003, PM's name no longer appeared. ${ }^{51}$ The AGA, the Nevada Resort Association, and the National Restaurant Association, as well as other tobacco industry allies, remained publicly listed as members. ${ }^{51}$

\section{ASHRAE standard 62: mobilising the gambling industry}

ASHRAE is an international organisation that develops, through committees, standards for heating, ventilation, refrigeration, and air conditioning. The tobacco industry has aggressively lobbied ASHRAE to see that its indoor air standard, Standard 62, continues to be consistent with smoking. ${ }^{9}$ At ASHRAE, the debate regarding ventilation standards and secondhand smoke has historically involved two camps. The tobacco industry and its allies support the development of standards based on "comfort" that specify ventilation levels related to the amount of smoking. Health advocates note that no economically feasible level of ventilation can control the health dangers associated with secondhand smoke and advocate "source control", which leads to standards based on the assumption of no smoking.

Elia Sterling is an ASHRAE member and president of Theodore Sterling Associates Ltd, a Canadian firm (founded by Elia's father, Theodore) whose financial ties to the tobacco industry date back as far as $1973 .{ }^{10}{ }^{52}$ In 1983 ASHRAE, to the delight of RJR, ${ }^{53}$ appointed Sterling a consulting/non-voting member of the Standard 62 Committee to review the then current Standard 62-1981..$^{54}$ By September 1988, the committee had revised the standard so that it assumed a "moderate amount of smoking" and in 1989 the standard was approved by the ASHRAE board of directors as Standard 62-1989. ${ }^{9}$ In 1993, Sterling was appointed as liaison between the Standard 62 Committee and an ASHRAE technical committee on building commissioning (the start up process for new buildings). As liaison, Sterling continued to have a formal involvement with Standard 62 and in 1994 was a voting member of the Standard 62 Committee. ${ }^{55}$ Historically, 
Sterling played a key role pressing for standards that allow smoking. ${ }^{9}$

After 1994, following a suggestion by tobacco industry lawyers, Sterling and Associates moved their focus away from attacking the science on secondhand smoke and towards indoor air quality (IAQ). ${ }^{10}$ As of December 2003, Sterling was serving as technical advisor to the AGA on indoor air quality ${ }^{56}$ and was participating in ASHRAE to promote the position that ventilation standards for casinos should be based on continued smoking. ${ }^{57}$

At the 1996 ASHRAE winter meeting, the Standard 62 Committee submitted a draft update of Standard 62 based on source control to ASHRAE members and the public for review. In response, the tobacco industry launched a campaign against source control that generated over 900 public comments against the proposed standard. ${ }^{9}$ As part of their campaign, PM gave a presentation to the AGA on 29 October 1996 that included over 25 high level gambling executives. $^{5859} \mathrm{PM}$ claimed that the standard would "not provide for acceptable indoor air quality where smoking occurs", would make the "owner and designer responsible for health of occupants", and would "create a liability for building owners and operators". ${ }^{60}$ PM encouraged the gambling industry to "demand a seat at the table during standards development" and provided instructions on how to submit public comment to ASHRAE. ${ }^{60}$ Logue reported to her PM co-workers that the presentation had been "very well received and resulted in very good initiative by the AGA in submission of comments on ASHRAE Standard $62 \mathrm{R}^{\prime \prime} .{ }^{61}$

Similarly, a PM briefing book on the public review draft of Standard 62 given to its allies in the hospitality industry included a section on the alleged impacts the new standard would have on casino owners and operators and suggested a "basis for comment". It included six different templates of "sample [ASHRAE] comments for casinos". ${ }^{62}$ Comments submitted by tobacco industry consultants and allies in the hospitality industry suggested rewording the standard so that IAQ for areas where smoking was permitted was defined by "comfort" rather than health. ${ }^{9}$ In 1997, the Standard 62 Committee started to review the comments. However, in July, on a motion by tobacco industry consultant Milton Meckler, the ASHRAE board of directors rejected the Standard 62 Committee's recommendation for a health based source control standard and instead put Standard 62 under "continuous maintenance". ${ }^{9}$ Logue described this as a "major victory for us [PM]"63 because it created a situation in which the tobacco industry-and its allies in the gambling industry-could press continuously for changes that served their interests.

In 1997 and 1998 PM WRA used a consultant to help the gambling industry submit comments to ASHRAE. The PM WRA 1998 budget included $\$ 50000$ for Susan Floyd, ${ }^{64}$ who worked on IAQ standards with PM corporate affairs and the "Casino Association" to submit comments to ASHRAE ${ }^{65}$

In addition to Floyd, Elia Sterling may have played a role connecting tobacco and gambling interests at ASHRAE. In 1998 and 1999, as technical committee liaison, Sterling was a voting member of the Standard 62 Committee. ${ }^{66}{ }^{67}$ In April 1999, handwritten notes in a PM file titled "ASHRAE Attorney Notes" explain that the AGA, while becoming more involved with ASHRAE, was frustrated by the HCIAQ and was suspicious of the restaurant and hotel associations. A question in the notes asks whether or not gambling should meet with PM "off line", with Elia Sterling's name mentioned and circled in this context. ${ }^{68}$ Despite the efforts of the tobacco industry and their allies, in 1999 ASHRAE published Standard 62-1999, which assumed no smoking. ${ }^{9}$

Due to an editorial oversight, smoking lounges, bars, cocktail lounges, and casinos were still left out of Standard

\section{What this paper adds}

Previous studies have demonstrated the tobacco industry's worldwide programme to co-opt the hospitality industry to fight against smoke-free environments, as well as the tobacco industry's efforts to promote ventilation as a "solution" to secondhand smoke. This paper demonstrates that the tobacco industry had a sophisticated and successful plan to incorporate the gambling industry into these efforts. With the continued proliferation of legalised gambling, public health advocates, decision makers, and the public need to understand the relationship between the tobacco and gambling industries. Gambling industry efforts to establish ventilation standards that include smoking for the hospitality industry and their opposition to smoke-free environments in general have been directed by the tobacco industry.

62. By the beginning of 2002, ASHRAE noted that "future addenda will eliminate this 'inconsistency' by providing separate guidance on determining the ventilation rates for these spaces (and other spaces) where smoking is permitted in them" ${ }^{\prime 69}$ In the meantime, representatives of the gambling industry with ties to PM worked to promote a standard that was consistent with smoking in casinos. At the ASHRAE Atlantic City meeting in January 2002, a seminar titled "Casino ventilation - keeping gamblers comfortable" included four presentations from four different engineers, including Sterling, that had all had previous connections to PM (table 1). No one with a health perspective was invited to participate.

Perhaps because of growing resistance to include smoking in Standard 62, in 2003 the AGA, in coordination with tobacco industry allies, the National Restaurant Association, the Nevada Resort Association, ${ }^{70}$ and the Hotel Association of Canada, ${ }^{41}$ sought support from ASHRAE membership to petition ASHRAE to require development of a separate standard for facilities in the hospitality industry. ${ }^{72} \mathrm{~A}$ publication from the AGA explains that at the June 2003 ASHRAE meeting "Gaming industry representatives outnumbered all other groups, including anti-smoking organizations attending the forum [What's needed in an ETS design guide?]" in order to deliver comments that would influence the ASHRAE board of directors in their development of a stand alone publication on ETS design issues. ${ }^{73}$ Another AGA publication regarding ASHRAE explains that "A hospitality coalition for indoor air quality (IAQ)" has funded a study conducted by Elia Sterling examining the impact of ventilation systems on the air quality of a modern casino and is funding a new study, to be conducted by Sterling to update those results. ${ }^{74}$ Consistent with the tobacco industry's strategy to stay behind the scenes, their allies have taken the lead presenting the tobacco industry's position at ASHRAE, encouraging the creation of a special committee that would develop ventilation standards specifically for the hospitality industry. As of December 2003, the AGA was nearing its goal of collecting enough signatures to petition ASHRAE. ${ }^{74}$

\section{DISCUSSION}

Because of its lack of credibility and poor public image, the tobacco industry works behind the scenes through front groups and public relations firms in order to protect its market and promote policy positions favourable to the industry. ${ }^{2-4}{ }^{75-80}$ Tobacco industry strategies to mobilise the gambling industry to oppose smoke-free environments are consistent with their efforts to co-opt and manipulate the hospitality industry. ${ }^{40}$ The tobacco industry has a history of 
financing (directly or indirectly) economic impact studies claiming that smoke-free environments have a severe negative impact on the hospitality industry, ${ }^{82}{ }^{80}$ and have worked to promote ventilation as the solution to secondhand smoke for the hospitality industry. ${ }^{10}$ By secretly organising an economic impact study that promoted the assertion that smoking restrictions would have a negative economic impact on Nevada casinos and by working to organise and promote ventilation in casinos, the tobacco industry has created additional third party allies who accept the assertion that it is in their best interest to "accommodate" ${ }^{\prime 4}$ smokers and nonsmokers and that ventilation is the solution to the secondhand smoke.

At least in the USA, as the tobacco industry's claims that smoke-free policies would adversely affect restaurants and bars have lost credibility, ${ }^{42}$ so the gambling industry has become increasingly important in championing the tobacco industry's agenda of promoting ventilation. In particular, as ASHRAE Standard 62 has evolved to be based on the assumption of non-smoking, ${ }^{9}$ the tobacco industry has relied more heavily on the gambling industry to press for ventilation standards that permit smoking. (Elia Sterling, whose firm has long time ties to the tobacco industry, now represents gambling interests in this process.) Consistent to previous tobacco industry strategies to form "independent" organisations to influence independent research, ${ }^{77}{ }^{81} \mathrm{PM}$ has worked behind the scenes in the USA to form the HCIAQ ${ }^{51}$ to mobilise the AGA and other allies in the gambling and hospitality industries to become involved in separating the hospitality industry from smoke-free ventilation standards. By late 2003, unable to derail Standard 62, the AGA, the National Restaurant Association, the Nevada Resort Association, and the Hotel Association of Canada-all tobacco industry allies-were pressing ASHRAE for a separate indoor air ventilation standard for the hospitality industry.

The tobacco industry's links to the gambling industry are not limited to working with national associations representing the American casino industry, nor are they limited to the USA. For example, allies of the tobacco industry with interests in video gambling machines secured state legislation pre-empting local communities in Montana from implementing smoke-free policies. On 4 June 2002, Helena, the state capital of Montana, implemented a citywide smoke-free ordinance that included all workplaces, restaurants, bars, and casinos. ${ }^{82}$ However, the ordinance was suspended after the operators of the Montana Nugget Casino convinced a court that the municipal infraction language written into the ordinance was unconstitutional because it did not allow for a jury trial. ${ }^{83}$

While the city was appealing this verdict, bar, tavern, and casino operators opposing the ordinance successfully lobbied for passage of a revenue bill, which did not have to go through a Health or Human Service Committee, that preempted local tobacco control by imposing an annual permit surcharge fee of \$200 for each gambling machine permit. In addition, the bill exempted "establishments that have permitted video gambling machines on the premises from local government ordinances on smoking that are more restrictive than state laws on smoking" ${ }^{84}$

Consistent with its strategies to prevent local control from behind the scenes, ${ }^{2}{ }^{76}$ the tobacco industry itself did not publicly lobby for the bill. However, the primary lobbyist for the bill was Mark Staples ${ }^{85}$ representing the Montana Tavern Association, an association that has had continuous financial ties with the tobacco industry since at least 1995 (table 1). Staples testified, without presenting any specific supporting data, that in Helena "the economic fall-out [of the smokefree ordinance] was swift and it was deep and serious". ${ }^{85}$
Despite opposition from a coalition of public health groups, ${ }^{86}$ the bill passed through the legislature in just 22 days. On 23 April 2003, 11 days after passing through the legislature and 33 days after being introduced, the governor signed it into law. ${ }^{87}$ Since gambling licences are easily issued (20 544 video gambling machine permits were issued in fiscal year $2003^{88}$ ) and the businesses need not actually have gambling, the state essentially implemented the tobacco industry's goal of state pre-emption ${ }^{75} 89$ by allowing a restaurant or bar to simply buy a single \$200 gambling licence which permitted them to continue smoking.

While the tobacco industry has utilised gambling connections successfully in Montana and Nevada, similar connections in Delaware ${ }^{90}$ have not prevented smoke-free gambling facilities. ${ }^{92}$ Since the tobacco and gambling alliance is relatively new in the USA, it is too early to tell whether or not the tobacco industry's efforts will be generally successful or not. In a similar manner to its efforts in the USA, beginning in at least 1993, the tobacco industry funded the Australian Hotels Association (AHA), a high profile lobby group with strong ties to the tobacco industry, which has played an active role voicing opposition of smoke-free workplaces. $^{93}$ (In Australia, bars and taverns are known as "hotels" and, depending on the gambling regulations set by individual provinces, hotels are permitted to operate electronic gambling machines.) In 2001, the tobacco industry financed the AHA in Tasmania to oppose smoke-free legislation through surveys, promotional videos, and information packets for members of the Parliament. ${ }^{93}$ While, by 2003, most workplaces in Tasmania were smoke-free by law, an exemption for gaming facilities states that smoking is permitted in all indoor gambling areas, unless food other than confectionery or snacks is available or consumed. ${ }^{94}$

\section{Limitations}

The proliferation of gambling in the USA has come mostly around the same time or after the 1998 legal settlements that made tobacco industry documents public information. As a result, tobacco industry executives have been aware after 1998 that their documents would be available to the public and may have become more circumspect in what they wrote down in their internal communications. Thus, evidence in tobacco industry documents of direct tobacco industry involvement in policy change and activities through the gambling industry after this time may be less detailed and concrete.

\section{Conclusion}

Worldwide tobacco industry strategies to avoid smoke-free gambling facilities are consistent with the industry's past efforts co-opting the hospitality industry to fight against smoke-free environments. Alliances with the gambling industry simply represent the newest in a long string of efforts by the tobacco industry to mobilise third parties to support its interests. The expansion of legalised gambling in the USA-as of August 2003, 30 US states had gambling devices including video lottery terminals and 24 states had at least one casino $0^{95}$ - and in many countries throughout the world represents new opportunities for the tobacco industry to mobilise existing allies, create new ally groups, and to continue to fight their policy battles against smoke-free environments from behind the scenes.

The implementation of tobacco industry strategies has been successful in collaboration with the gambling industry for three main reasons. First, unlike many in the hospitality industry $^{10}$ the gambling industry has already invested in the construction of expensive ventilation systems as a solution to secondhand smoke. Second, claims by the tobacco and gambling industries that smoke-free environments hurt 
gambling revenue, except for bingo, have not been discredited. ${ }^{96}$ Finally, consistent with its strategies to influence policy formation at the state level and worldwide, the tobacco industry has used its connections with the gambling industry to wield its power from behind the scenes. Tobacco control advocates need to be aware of these connections and work to expose them to the public and public policy makers.

\section{ACKNOWLEDGEMENTS}

This research was supported in part by National Cancer Institute grants CA-61021 and CA-87472. Professor Glantz holds a Cahan Distinguished Professorship from the Flight Attendant Medical Research Institute.

\section{Authors' affiliations}

L L Mandel, S A Glantz, Center for Tobacco Control Research and Education, University of California, San Francisco, San Francisco, California, USA

\section{REFERENCES}

1 Glantz S. Achieving a smokefree society. Circulation 1987;76:746-52.

2 Samuels B, Glantz S. The politics of local tobacco control. JAMA 1991;266:2110-7

3 Traynor M, Begay M, Glantz S. New tobacco industry strategy to prevent local tobacco control. JAMA 1993;270:479-86.

4 Dearlove J, Bialous S, Glantz S. Tobacco industry manipulation of the hospitality industry to maintain smoking in public places. Tobacco Control 2002; 11:94-104.

5 Barnoya J, Glantz S. Tobacco industry success in preventing regulation of secondhand smoke in Latin America: the "Latin Project". Tobacco Control 2002;11:305-14.

6 Muggli M, Hurt R, Blanke D. Science for hire: a tobacco industry strategy to influence public opinion on secondhand smoke. Nicotine Tob Res 2003:5:303-14.

7 Fichtenberg C, Glantz S. Effect of smoke-free workplaces on smoking behaviour: systemic review. BMJ 2002;325:1-7.

8 Dearlove J, Glantz S. Boards of health as venues for clean indoor air policy making. Am J Public Health 2002;92:257-65.

9 Bialous S, Glantz S. ASHRAE Standard 62: tobacco industry's influence over national ventilation standards. Tobacco Control 2002;11:315-28.

10 Drope J, Aguinaga-Bialous S, Glantz S. Tobacco industry efforts to presen ventilation as an alternative to smokefree environments in north america. Tobacco Control 2004;13:i41-7.

11 American Gaming Association. Is Legalized Gambling a \$600 Billion Industry or a $\$ 50$ Billion Industry? 1999. http://www.americangaming.org/ industry/factsheets/general_info_detail.cfv?id = 11 [Accessed Mar 17, 2004].

12 Malone R, Balbach E. Tobacco industry documents: treasure trove or quagmire? Tobacco Control 2000;9:334-8

13 Anon. Philip Morris Companies Inc. Legal Department Five Year Plan 19941998. 1994. Philip Morris. Bates No. 2500041871/1899. http:// legacy.library.ucsf.edu/tid/Ifc87e00 [Accessed 27 Oct, 2003].

14 Anon. Transcript. 8 Sep, 1993. Philip Morris. Bates No. 2025842339/ 2342. http://legacy.library.ucsf.edu/tid/bsr95e00 [Accessed 27 Oct, 2003].

15 Trotter L, Chapman S. "Conclusions about exposure to ETS and health that will be unhelpful to us": How the tobacco industry attempted to delay and discredit the 1997 Australian National Health and Medical Research Council report on passive smoking. Tobacco Control 2003;12(suppl III):iii102-6.

16 Goodheart J. Burswood Decision. 4 Oct, 1993. Philip Morris. Bates No.2025837158/7159. http://legacy.library.ucsf.edu/tid/wwq95e00 [Accessed 27 Oct, 2003]

17 Occupational Health and Safety Administration. Indoor air quality [Docket $\mathrm{H}-122]$. Federal Register; 5 April, 1994:15968-16039.

18 Bryan-Jones K, Bero L. Tobacco industry efforts to defeat the occupational safety and health administration indoor air quality rule. Am J Public Health 2003:93:585-92.

19 Burton J, Carlisle R, Duchane G, et al. Proceedings of the Workshop on Ventilation Engineering Controls for Environmental Tobacco Smoke in the Hospitality Industry. 7 June 1998. Philip Morris. Bates No.2072603733/ 3843. http://legacy.library.ucsf.edu/tid/phf42c00 [Accessed 4 Sept, 2003].

20 Dobra J. Economic Impacts of the Proposed OSHA Smoking Ban on the State of Nevada. Dec, 1996. Philip Morris. Bates No. 2072360688/071 1. http://legacy.library.ucsf.edu/tid/xzx97d00 [Accessed 30 Sept, 2003]

21 OSHA Communications Report (Status as of July 18, 1996). Philip Morris. 18 Jul, 1996. Philip Morris. Bates No. 2061897534/7535. http:// legacy.library.ucsf.edu/tid/gqw47d00 [Accessed 23 Jan, 2003]

22 OSHA Communications Report August 1, 1996. August 1, 1996. Philip Morris. Bates No. 2061897515/7516. http://legacy.library.ucsf.edu/tid/ cqw47d00 [Accessed 6 Mar 2003]

23 Sorrells J. OSHA Communications Report 12/20/1996. Philip Morris. 20 Dec, 1996. Bates No. 2078123205/3206. http://legacy.library.ucsf.edu/ $\mathrm{tid} / \mathrm{wyu} 75 \mathrm{c00}$ [Accessed 23 Jan, 2003].
24 Becker D. Grant Requests. 7 Jan, 1997. Philip Morris. Bates No. 2078346715. http://legacy.library.ucsf.edu/tid/ijo72c00 [Accessed 29 Aug, 2003]

25 OSHA Projects. Jan, 1997. Philip Morris. Bates No. 2064247100/7438. http://legacy.library.ucsf.edu/tid/xqv93c00 [Accessed 4 Sept, 2003]

26 Rapp M. Fax Cover Sheet. 3 Dec, 1996. Philip Morris. Bates No. 2064229416. http://legacy.library.ucsf.edu/tid/fyv93c00 [Accessed 3 Oct, 2003].

27 Associated Press. Smoking Ban Plan Upsets Nevada. 5 Dec, 1996. Philip Morris. Bates No. 2072360720. http://legacy.library.ucsf.edu/tid/ cay97d00 [Accessed 26 Dec, 2003]

28 Chereb S. Smoking Rules Could Burn Tourism[Reno Gazette Journal]. 5 Dec, 1996. Philip Morris. Bates No. 2072360721. http:// legacy.library.ucsf.edu/tid/day97d00 [Accessed 26 Dec, 2003]

29 Whaley S. N921. 5 Dec, 1996. Philip Morris. Bates No. 2072168617 http://legacy.library.ucsf.edu/tid/vdl27d00 [Accessed 26 Dec 2003].

30 No Author. Smoking Ban Plan Upsets Nevada [San Francisco Chronicle]. 5 Dec, 1996. Philip Morris. Bates No. 2065455548. http:// legacy.library.ucsf.edu/tid/xmi73c00 [Accessed 26 Dec, 2003].

31 Chereb S. Smoking Rules May Hurt Casinos [Carson City, NV Appeal]. 5 Dec, 1996. Philip Morris. Bates No. 2065455551. http:// legacy.library.ucsf.edu/tid/zmi73c00 [Accessed 26 Dec, 2003].

32 Scollo M, Lal A, Hyland A, et al. Review of the quality of studies on the economic effects of smoke-free policies on the hospitality industry. Tobacco Contol 2003; 12:13-20.

33 Singleton J. Goals. 1996. RJ Reynolds. Bates No. 522904788/4789. http://legacy.library.ucsf.edu/tid/rkl60d00 [Accessed 27 Oct 2003]

34 Logue M. N921: Casino/Resort Gaming Industry. Philip Morris. 27 Jan, 1997. Philip Morris. Bates No. 2072168619/8620. http:// legacy.library.ucsf.edu/tid/xdl27d00 [Accessed 10 Mar, 2003].

35 Media Relations Plan Places. Philip Morris. Jun, 1998. Philip Morris. Bates No. 2072909429/9445. http://legacy.library.ucsf.edu/tid/awt27d00 [Accessed 10 Mar, 2003].

36 Anon. Public Smoking Ban 'Hazard to Economy'. 4 Mar, 1975. Philip Morris. Bates No. 2025027427. http://legacy.library.ucsf.edu/tid/ dkd35e00 [Accessed 27 Oct, 2003]

37 Chilcote S. Winter Meeting Program. 3 Feb, 1984. Brown and Williamson. Bates No. 517001342. http://legacy.library.ucsf.edu/tid/iop24f00 [Accessed 27 Oct, 2003].

38 Meyne R. It Was a Pleasure Meeting with You to Discuss Proposed Smoking Bans and the Impact They Would Have on the Gaming Industry. 6 Mar, 1996. RJ Reynolds. Bates No. $517112687 / 2688$. http:// legacy.library.ucsf.edu/tid/zls60d00 [Accessed 27 Oct, 2003].

39 Workplace Smoking, N403. Jul, 1995. Philip Morris. Bates No. 2048551863. http://legacy.library.ucsf.edu/tid/coc57d00 [Accessed 14 Nov, 2003].

40 Givel M, Glantz S. The "global settlement" with the tobacco industry: six years later. Am J Public Health 2004:94:218-24.

41 Mcdaniel J. Gaming Convention Vegas. 25 Nov, 1997. Philip Morris. Bates No. 2070292705A. http://legacy.library.ucsf.edu/tid/bjol6c00 [Accessed 27 Oct, 2003]

42 Anon. Situation Analysis: The Gaming Industry and Accommodation at a glance. Philip Morris. Feb, 1998. Philip Morris. Bates No. 2072148493/ 8498. http://legacy.library.ucsf.edu/tid/Ifl06c00 [Accessed 5 Mar, 2003].

43 Gross D. Casino Background. Philip Morris. 27 Apr, 1999. Philip Morris. Bates No. 2072395870. http://legacy.library.ucsf.edu/tid/akp27d00 [Accessed 8 Apr, 2003].

44 Anon. N921. Dec, 1999. Philip Morris. Bates No. 2072395608/5610. http://legacy.library.ucsf.edu/tid/zlp27d00 [Accessed 11 Dec, 2003].

45 Black Kelly Scruggs \& Healey. N921 Memorandum Re: The Day's Events and Requisite Follow-Up. Philip Morris. $16 \mathrm{Jul}$, 1999. Philip Morris. Bates No. 2072395769/5771. http://legacy.library.ucsf.edu/tid/lkp27d00 [Accessed 10 Apr, 2003]

46 Culley E. N921. 31 Jan, 2000. Philip Morris. Bates No. 2072395494. http://legacy.library.ucsf.edu/tid/dop27d00 [Accessed 11 Dec, 2003]

47 Caldeira S, Culley E, Geovannello F. Re: 2001 NRA Show Plan. 16 Jan, 2001. Philip Morris. Bates No. 2080405495/5499. http:// legacy.library.ucsf.edu/tid/Irul4c00 [Accessed 11 Dec, 2003]

48 HCIAQ Highlights. Mar, 2001. Philip Morris. Bates No. 2085131640. http://legacy.library.ucsf.edu/tid/fczOOc00 [Accessed 11 Dec, 2003].

49 Internet Archive. Archival copy of www.hcaiq.org as of 25 Jan, 2003http:// web.archive.org/web/20030712004622/hciaq.org/members.htm [Accessed 3 Jan, 2004].

50 Internet Archive. Archival copy of www.hciaq.org as of 11 Jun, 2003http:// web.archive.org/web/20030712004622/hciaq.org/members.htm [Accessed 3 Jan, 2004].

51 Hospitality Coalition on Indoor Air Quality. webpage. HCIAQ, 2003 www.hciaq.org [Accessed 29 Dec, 2003].

52 Glantz S, Slade J, Bero L, et al. Cigarette papers. University of California Press, 1996.

53 Nystrom C. Weekly Highlights. R. J. Reynolds. 8 Dec, 1982. R. J. Reynolds. Bates No. 500883736/3737. http://legacy.library.ucsf.edu/tid/fcy59d00 [Accessed 23 Dec, 2003]

54 SPC 62-1981R Roster Ventilation for Acceptable Indoor Air Quality Lorillard. 1983. Bates No. 87697520/7521. http:// legacy.library.ucsf.edu/tid/vqo21 e00 [Accessed Dec 20, 2003]

55 ASHRAE. ASHRAE Roster 1994-T-STDS-SSPC62 Ventilation for Acceptable Indoor Air Qaulity. ASHRAE, 1994.

56 American Gaming Association. webpage. American Gaming Association, 2003. www.americangaming.org [Accessed Dec 20, 2003] 
57 ASHRAE. Seminar 15 Casino Ventilation - Keeping Gamblers Comfortable TC 05.05 Air-to-Air Energy Recovery. ASHRAE Winter Meeting. Atlantic City, NJ: ASHRAE2002.

58 Anon. [List]. Oct, 1996. Philip Morris. Bates No. 2081753846. http:// legacy.library.ucsf.edu/tid/sag45c00 [Accessed Sept 12, 2003].

59 American Gaming Association Indoor Air Quality Briefing Tuesday, 961029, 1:00 3:30 P.M. Mirage Hotel, Ballroom C. 29 Oct, 1996. Philip Morris. Bates No. 2081753845. http://legacy.library.ucsf.edu/tid/ rag 45c00 [Accessed Sept 12, 2003]

60 Proposed Changes to ASHRAE's Standard 62 "Ventilation For Acceptalbe Indoor Air Quality". Philip Morris. 29 Oct, 1996. Philip Morris. Bates No. 2065514467/4484. http://legacy.library.ucsf.edu/tid/cob73c00 [Accessed Apr 9, 2003].

61 Logue M. RE: Gaming Convention/Las Vegas. Philip Morris. 3 Dec, 1997 Philip Morris. Bates No. 2078199369B. http://legacy.library.ucsf.edu/tid/ sct75c00 [Accessed Feb 28, 2003].

62 Anon. Briefing Book Public Review Draft 62r. 24 Oct, 1996. Philip Morris. Bates No. 2081753613/3826. http://legacy.library.ucsf.edu/tid/ mag45c00 [Accessed Dec 11, 2003].

63 Burnley H, Logue M. ASHRAE. 9 Jul, 1997. Philip Morris. Bates No. 2063573891/3894. http://legacy.library.ucsf.edu/tid/bnq22d00 [Accessed Dec 11, 2003]

64 Philip Morris Management Corp. Worldwide Regulatory Affairs Department 1998 Original Budget. Philip Morris. 12 Sep, 1997. Philip Morris. Bates No. 2074769068/9117. http://legacy.library.ucsf.edu/tid/nxe29c00 [Accessed April 8, 2003].

65 Projects. 13 May, 1998. Philip Morris. Bates No. 2065259668/9671. http://legacy.library.ucsf.edu/tid/jwq83c00 [Accessed Sep 8, 2003]

66 ASHRAE. ASHRAE Roster 1998-T-STDS-SSPC62.1P Ventilation \& Acceptable IAQ in Comm. Institut. \& High-rise Residential Bldgs. 1998.

67 ASHRAE. ASHRAE Roster 1999-T-STDS-SSPC62.1P Ventilation \& Acceptable IAQ in Comm. Institut. \& High-rise Residential Bldgs. 1999.

68 Anon. [Handwritten Meeting Minutes]. Apr, 1999. Philip Morris. Bates No. 2082722967. http://legacy.library.ucsf.edu/tid/ykl92c00 [Accessed Dec 15, 2003].

69 ASHRAE. Interpretation IC 62-2001-08 of ANSI/ASHRAE Standard 622001 Ventilation for Acceptable Indoor Air Quality; 2002.

70 American Gaming Association. Hospitality Industry Joins Forces to Clear the Air on Ventilation Standards. 2003. http//www.americangaming.org/ insidetheaga/inside_aga_detail.cfv?id = 81 [Accessed Dec 20, 2003].

71 Gray K. An Issue of Respect. 1997 (est.): 2073231999/2001.

72 American Gaming Association, National Restaurant Association, Hotel Association of Canada. Petition to establish a project committee for the hospitality industry. 2003. http://test.americangaming.org/assets/files/ ashrea_petition_with_intro_page.pdf [Accessed Dec 20, 2003].

73 American Gaming Association. Industry proves an effective force at ASHRAE forum. 2003. http://www.americangaming.org/insidetheaga/ inside_aga_detail.cfv?id = 164 [Accessed Dec 20, 2003]

74 American Gaming Association. AGA Takes Aggressive Steps for Indoor Air Quality at Casinos. 2003. http://www.americangaming.org/insidetheaga/ inside_aga_detail.cfv?id = 192 [Accessed Dec 20, 2003].

75 Siegel M, Carol J, Jordan J, et al. Preemption in tobacco control: review of an emerging public health problem. JAMA 1997;278:858-63.

76 Givel M, Glantz S. Tobacco lobby poitical influence on US state legislatures in the 1990s. Tobacco Control 2001;10:124-34.

77 Drope J, Chapman S. Tobacco industry efforts at discrediting scientific knowledge of environmental tobacco smoke: a review of internal industry documents. J Epidemiol Community Health 2001;55:588-94.

78 Drope J, Glantz S. British Columbia capital regional district 100\% smokefree bylaw: a successful public health campaign despite industry opposition. Tobacco Control 2003;12:264-8.

79 Tsoukalas T, Glantz S. The Duluth Clean Indoor Air Ordinance: problems and success in fighting the tobacco industry at the local level in the $21 \mathrm{st}$ century. Am J Public Health 2003;93:1214-21.

80 Ritch W, Begay M. Strange bedfellows: the history of collaboration between the Massachusetts Restaurant Association and the tobacco industry. Am J Public Health 2001;91:598-603.

81 Muggli M, Forster J, Hurt R, et al. The smoke you don't see: uncovering tobacco industry scientific strategies aimed against environmental tobacco smoke policies. Am J Public Health 2001;91:1419-23.

82 Anon. County to toughen enforcement of new ordinance. The Associated Press State \& Local Wire, 2002. 27 Jul. Sect.State and Regional.

83 City of Helena vs. G.N.C., Inc. Greg Straw c/o Montana Nugget Casino. 2002. City Court of Helena.

84 Delvin, Forrester, Gallus, Maedje, Shae, Tropila. House Bill No. 758. 12 Apr, 2003. Montana Legislature, 2003.

85 Montana Senate. Committee on Business and Labor. 2003 Regular ed. Helena: Montana Historical Society; 7 Apr, 2003.

86 Minutes. Senate Business and Labor. 58th Legislature Regular Session ed. Helena; 7 Apr, 2003.
87 Montana Legislature. Detailed Bill Information. 2003. http:// laws.leg.state.mt.us/pls/laws03/LAW0203W\$BSRV.ActionQuery? P_BLTP_BILL_TYP_CD $=$ HB\&P_BILL_NO =758\&P_BILL_DFT_ $\overline{N O}=\& Z \quad A C T I O N=$ Find \&P SBJ DESCR $=\& P$ SBJT SBJ $C D=\& P$ LST_NMI $=\& P \_E N T Y \_I D \_S E Q=[$ Accessed Mar 18, 2004]

88 Montana Department of Justice. Montana Gambling Statistics Prepared by the Montana Department of Justice as of November 30, 2003. Helena, MT: 2003.

89 Walls T. CAC Presentation Number 4 Tina Walls Introduction. 8 Jul, 1994. Philip Morris. Bates No. 2041183751/3790. http:// legacy.library.ucsf.edu/tid/vnf77e00 [Accessed Nov 14, 2003].

90 Mcglynn D. As You Know, Dover Downs Has Been Upgrading Its Facilities for Several Years Now. March 3, 1989. RJ Reynolds. Bates No. 516394879/4881. http://legacy.library.ucsf.edu/tid/uzy82d00 [Accessed August 29, 2003].

91 Chase R. Dover Downs blames layoffs on Delaware smoking ban. 2003. May 2.

92 American Lung Association. Tobacco Policy Trend Alert Clean Indoor Air: The Delaware Campaign Model; 2002 Nov.

93 Harper T, Martin J. Trojan Horses: how the tobacco industry infiltrates the smokefree debate in Australia. Austr N Z J Public Health 2002;26:572-3.

94 Department of Health and Human Services. Smoke-Free Areas-FAQ. 2003. http://www.dhhs.tas.gov.au/publichealth/smokefreeareas/faq.html [Accessed Dec 20, 2003].

95 Rose N. Gambling and the Law: Status of Gambling Laws. Encino: Whittier Law School, 20033 Aug.

96 Glantz S, Wilson-Loots R. No association of smokefree ordinances with profits from bingo and charitable games in Massachusetts. Tobacco Control 2003;12:411-13.

97 A E Associates. Proposal For Environmental and Engineering Services For Smoking Area Design Concepts. Philip Morris. 8 Sep, 1994. Bates No. 2063665496. http://legacy.library.ucsf.edu/tid/xrw83c00 [Accessed Apr 7, 2003].

98 A E Associates. Proposed meeting schedule for $1 / 17 / 95$ in Las Vegas, Nevada. Philip Morris. January, 1995. Philip Morris. Bates No. 2051002731/2732. http://legacy.library.ucsf.edu/tid/dmk79e00 [Accessed April 4, 2003]

99 Accommodation Ventilation Projects. 1997. Philip Morris. Bates No. 2078447397/7400. http://legacy.library.ucsf.edu/tid/fgm75c00 [Accessed Sept 29, 2003].

100 American Hotel \& Motel Association and the Accommodation Program Launch Partnership. Philip Morris. 7 May, 1997. Bates No. 2071573079/ 3080. http://legacy.library.ucsf.edu/tid/Igj08d00 [Accessed Mar 10, 2003].

101 Philip Morris. Ventilation Roundtable. Philip Morris. 23 March, 1998. Bates No. 2070693352/3355. http://legacy.library.ucsf.edu/tid/rkł37d00 [Accessed Aug 27, 2003].

102 Response to Addendum 62G Public Review. Philip Morris. Apr, 2001. Philip Morris. Bates No. 2082710514/0524. http://legacy.library.ucsf.edu/tid/ dil92c00 [Accessed Apr 4, 2003]

103 JBA Consulting Engineers. Ventilation in Las Vegas Casinos. June, 1998 Philip Morris. Bates No. 2505588441. http://legacy.library.ucsf.edu/tid/ qpc19c00 [Accessed Sept 4, 2003].

104 Serrano M. 2001 State Coalition Status Report Field Action Team. Philip Morris. 12 Mar, 2001. Philip Morris. Bates No. 2085257098/7152. http://legacy.library.ucsf.edu/tid/hzc22c00 [Accessed April 14, 2003].

105 Lattanzio T. [Letter]. Philip Morris. 16 Feb, 1995. Bates No. 2073712836. http://legacy.library.ucsf.edu/tid/qmt42c00 [Accessed Aug 5, 2003].

106 Durkee M. Remarks of Marie Durkee Executive Director Montana Tavern Association News Conference Jorgensons Restaurant and Lounge, Helena MT. Philip Morris. 11 Dec, 1996. Legacy Tobacco Documents. Bates No. 2065455431/5777. http://legacy.library.ucsf.edu/tid/yli73c00 [Accessed Jul 27, 2003]

107 Montana Tavern Association. Thank You For Your Continuing Support. R.J. Reynolds. 17 Dec, 1999. Bates No. 522498794/8795. http:// legacy.library.ucsf.edu/tid/zcv20d00 [Accessed July 29, 2003].

108 Lobbying Reports, CO, MT, NH, Lobbying. R.J. Reynolds. 4 Apr, 2001. Bates No. 525160810/0811. http://legacy.library.ucsf.edu/tid/lip20d00 [Accessed Aug 5, 2003].

109 OSHA Proposed First Federal Indoor Air Quality Rule. Washington DC: Bayley Reporting, Inc, 1994:7875-7943.

110 Nevada Legislature. Registered Lobbyists of the 2003 Session; 2003.

111 Carchman R, Ellis C, Opocensky M. Voucher. 26 Feb, 1997. Philip Morris. Bates No. 2063653946. http://legacy.library.ucsf.edu/tid/dig67e00 [Accessed Dec 11, 2003].

112 Merin C, Tiner M. N921. 17 Sep, 1999. Philip Morris. Bates No. 2072395689. http://legacy.library.ucsf.edu/tid/rkp27d00 [Accessed Oct 28, 2003].

113 HCIAQ Meeting Minutes. Philip Morris. 21 Sep, 2000. Philip Morris. Bates No. 2078849915/9919. http://legacy.library.ucsf.edu/tid/dhd36c00 [Accessed Apr 10, 2003]. 